\title{
Production and Marketing of Carp Species in Rupandehi, Nepal
}

\section{Sunil Das Patel, Rupak Karn*, Sagar Bhusal, Sujita Balami, Prabin Adhikari, Raju Kharel}

Agriculture and Forestry University, Rampur, Chitwan, Nepal

*Corresponding author e-mail: coolrupak99@gmail.com

\section{Doi: 10.2478/mjhr-2020-0001}

\section{Abstract:}

The research was conducted from January 2019 to June 2019 to study the fish production and marketing system in fish zone, Rupandehi. Altogether 95 respondents including 27 small farmers, 35 medium farmers and 33 large farmers were selected for household survey using simple random sampling for the study. Statistical tools, Ms- excel and SPSS of version 23 were used for data analysis. From the study, it was evident that, six species of carps of fingerlings size were stocked with high average number of common carps $(3885.5 / \mathrm{ha}$.) followed by silver carp $(3880.5 / \mathrm{ha})$. The average production of fish species was 6.06ton/ha which is slightly higher than the national average. The observed data revealed that, marketing of major quantity of fish was from on farm sale i.e. $55.78 \%$ followed by local market sale $(18.94 \%)$, live fish sale in retailers (5.26\%). Similarly, percentage of farmers selling fish to wholesaler, consumers, retailers and neighbours were $63.3 \%, 30.5 \%, 26.5 \%$ and $26.3 \%$ respectively. Cost and returns analysis showed average B/C ratio of 2.13 . Problem ranking using 5 point scale value showed high cost of feed as the most serious problem with index value of 0.94 in the study area.

Keywords: survey, cost, returns, marketing, B/C ratio

\subsection{Introduction:}

Fisheries is an important sub-sector of agriculture in Nepal and contributes to great percentage of GDP i.e. 2.79 in 2069/2070; 4.90 in 2070/2071; 6.31 in 2071/2072; 11.76 in 2072/073 and 6.86 in 2073/074 [1]. Aquaculture is the breeding and rearing of fish, shellfish, or plants in ponds, or any enclosure for direct harvest of the product, which is an area of activity growing rapidly [2]. Initiated on the mid-1940s, took its shape around the 1950s and 60s with the introduction of Common carp and significantly progressed at the beginning of 1970s with the introduction and farming of three exotic Chinese carp species: silver carp (Hypophthalmichthys molitrix), bighead carp (Aristichthys nobilis) and grass carp (Ctenopharyngodon idellus). Fish is acclaimed to be the principal source of animal protein for over one billion people globally as it is the cheapest source of animal protein, providing many important nutritional and health benefits [2]. At present, seven commercially valuable carp species are bred and cultured in the country, viz. three indigenous species; rohu (Labeo rohita), Naini (Cirrhus mrigala) and bhakur (Catla catla) and four are exotic species; Common carp (Cyprinus carpio), Silver carp (Hypopthalmichthys molitrix), Bighead carp (Aristichthys nobilis) and Grass carp (Ctenopharyngodon idella). The current domestic production meets only $40 \%$ of the total country's demand and about $60 \%$ of the total fish demand in Nepal comes from neighboring countries, mainly India. The top 10 highest fish producing districts are Bara, Chitwan, Dhanusha, Rupendehi, Parsa, Morang, Saptari, Mahottarri, Siraha and Sarlahi among them Bara has highest production [1]. Fishing is one of the important and traditional ways of life sustaining for low economic community like Tharu, Majhi, Mukhiya, Malaha, Dunuwar, Kewat, Jalari, Kumal, Bote, Musahar, Danger and others [3].

\subsection{Materials and methods}

\subsection{Selection of site (study area)}

The survey was carried out in Rupandehi, which is the Terai district located in Province No. 05. Its neighbor districts are Kapilvastu in the west, India in the south, Nawalparasi to east and Palpa in the northern part. Administratively, the district has 7 rural-municipalities and 6 Municipalities. Geographically, the district is spread ranging the altitude from 100 masl to 1229 masl.The temperature ranges from $37^{\circ} \mathrm{C}$ as maximum and $2^{\circ} \mathrm{C}$ as minimum having the annual average rainfall $1367 \mathrm{~mm}$. Mostly monsoon concentrate from June to middle of the September of the year and little in winter rainfall. The district has 241587 hectare land of which 100,149 hectare is cultivable and remaining is covered by forest, watersheds and grazing land (1). It covers area of 1350 sq.km and has population of 8, 80,196 with average population density of 647 people/ $\mathrm{km} 2$ (2). The study was carried out in four rural municipalities of Rupandehi district under Fish Zone, Rupandehi PIU namely Siyari, Mayadevi, Gaidahawa and Sudhhodhan. These areas are purposively selected because majority of fish farmers i.e. about $80 \%$ are from these areas and contribute about 800 hectares of pond area about $75 \%$ of total fish production of the whole district.

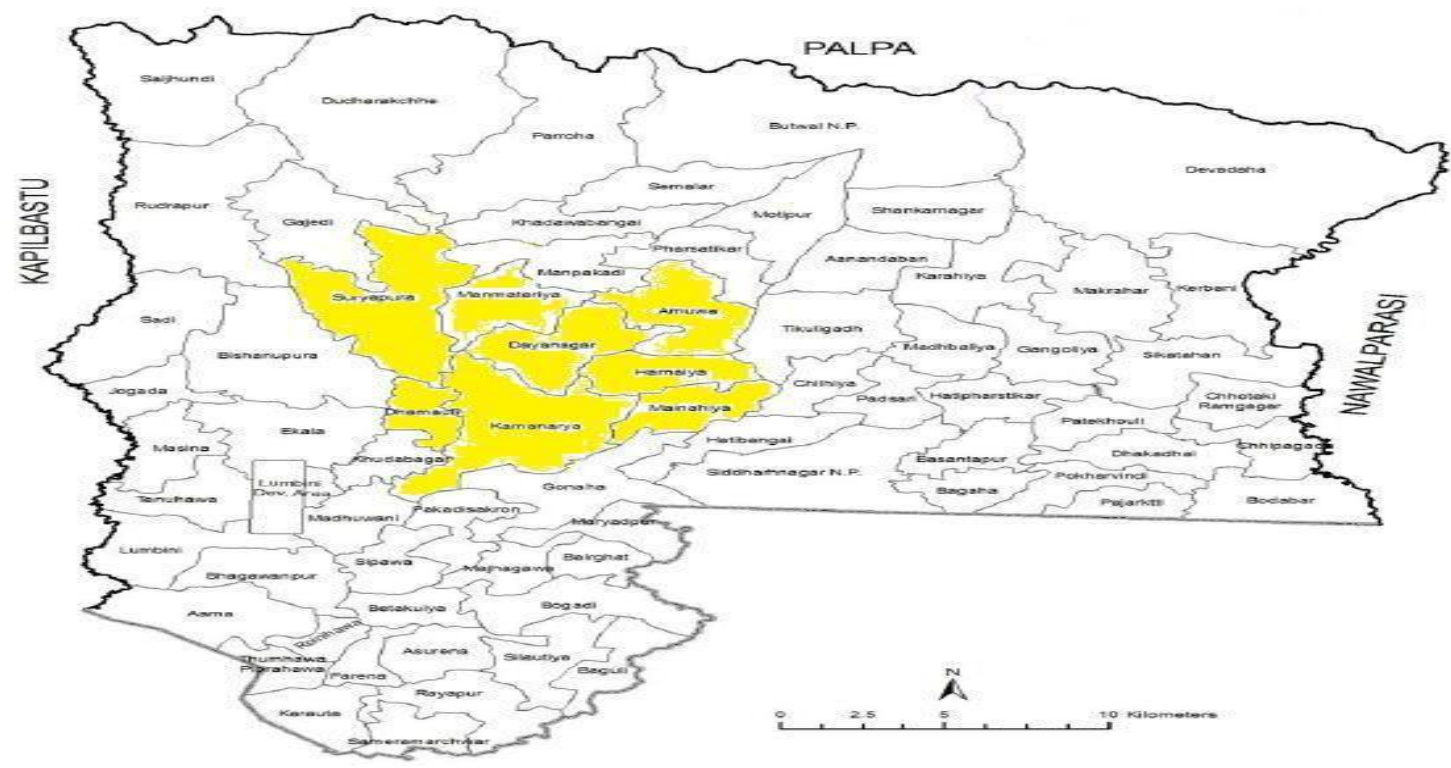

Figure 1: Location of Study site

\subsection{Study design, sampling procedure, sampling method}

The survey was carried out with pre tested semi-structured interview based schedule in 95 randomly selected households under carp polyculture system. Beside this, to support the primary data FGD and KII was conducted with local wholesalers and retailers (community groups) and local manufacturers. Secondary information was obtained through discussion with fish experts, Agriculture Officer (Fish) DADO, from DADO reports, journals.

In the beginning of the study commercial fish farmers of the survey area were identified and listed. For this data, Fish Zone Profile FY 2074/075 was used. It was analyzed and listed with the help of Fish Zone, Rupandehi PIU agriculture officer, TAs and zone conducting committee members. To complement the 
household survey, visiting along with TAs, discussion with experts, onsite identification of disease was carried out. The samples were collected using simple random sampling techniques.

\subsection{Sources of data, techniques of data collection, observation}

For the collection of the necessary information various data collection techniques were used. Most of information for the study was primary data collected through pre-tested questionnaire which was administered to the respondents. Similarly, Focused Group Discussion (FGD) was done to identify the major problems in carp poly culture feeding practice and to support the information collected through interview scheduling.

Secondary data were collected from the various sources, PMAMP zone profile, District annual report, district profile, annual progress report and statistic book of DADO, Rupandehi, fish profile book of DADO, Rupandehi, various report from Ministry of Agriculture Development (MoAD), Central Bureau of Statistics (CBS), cooperatives, bulletins, books, publications from different governmental and non-governmental organizations, journals, proceedings of various NGOs and INGOs were the sources of secondary information for the study. Different techniques such as: interview, FGD, KII, field observation were employed for the collection of necessary information. A number of visits were made to the study sites by the researcher during the survey times and direct observation were made on pond water quality, technological advancement and different farm activities.

\subsection{Survey design and data collection procedure and data analysis technique}

This section deals with the designing of interview schedule and data collection procedures followed during the field works in the Rupandehi district. Several data were collected during this visit. These helped in preparing the questionnaire model and sampling procedure. The collected data were edited and the local units of measurements were standardized into the scientific one. All the important primary data that were collected from households were entered in Ms-Excel and Statistical Package for Social Science (SPSS) program (Version 23.0) for further analysis. Collected data were analyzed using the descriptive and inferential statistics.

\subsection{Chi-square test or test of independence}

In order to study the weather two variables were independent or associated with each other; chi-square was applied.

$$
\chi 2=\backslash \operatorname{sum} \backslash \operatorname{frac}\left\{\left\{\left(\mathrm{O}_{-}(\mathrm{ij}\}-\mathrm{E}_{-}\{\mathrm{ij}\}\right)\right\}^{\wedge} 2\right\}\left\{\mathrm{E}_{-}\{\mathrm{ij}\}\right\}
$$

Where, $\chi 2=$ Chi-square

$\mathrm{O}_{-}\{\mathrm{ij}\}=$ observed frequency of each $\mathrm{ijth}$ term

E_ $\{\mathrm{ij}\}=$ indicates expected frequency of $\mathrm{ijth}$ term

$\mathrm{i}=1,2,3$.

$\mathrm{j}=1,2,3 \ldots \ldots \ldots \ldots \mathrm{k}$

This was tested at 0.05 level of probability for different degree of freedom.

\subsection{Benefit cost analysis}

Benefit cost analysis was done after calculating the total cost and gross return from the rice cultivation. Cost of production was calculated by summing the variable cost items in the production process[4]. For calculating gross return, income from product sale was accounted[5]. Therefore, the benefit cost analysis was carried out by using formula:

$$
B / C \text { ratio }=\frac{\text { Gross return }}{\text { Total } \cos t}
$$

\subsection{Problems in production}

Qualitative data were taken into account to prepare the index. On the basis of responded frequencies, weighted indexes were calculated for the analysis of farmer's perception on the extent of production. Farmer's perception to the different production problems were ranked by using five-point scales. Then the priority index was calculated by weight age average mean in order to draw valid conclusion.

The index of importance was computed by using the formula:

$\mathrm{I}_{\mathrm{imp}}=\sum \frac{\text { Sifi }}{N}$

Where,

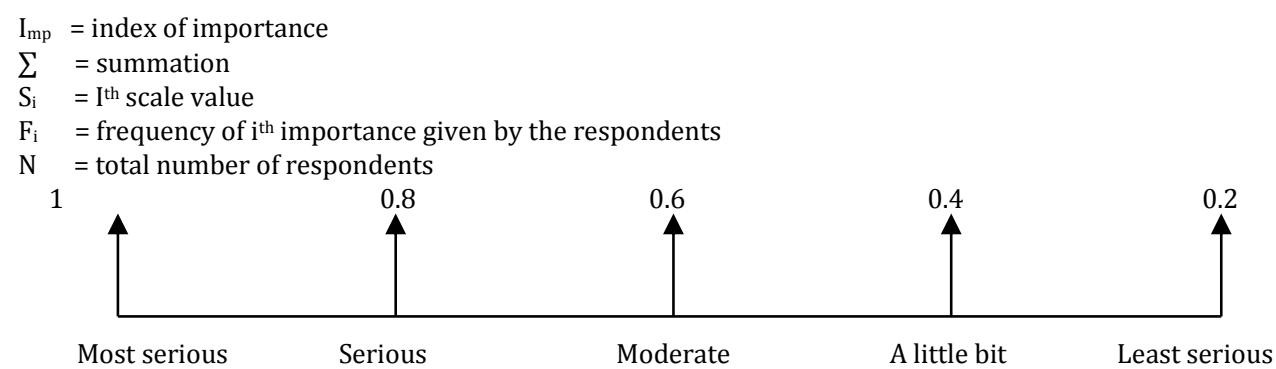

Figure 2: Scale of rating

\subsection{Result and Discussion}

\subsection{Stocking rate of different species of carps}

Commonly in fish zone Rupandehi, six species of carps were stocked with average number of fingerlings of silver carps 3880.5 per ha with average number of bighead carps of 916.2 per ha, with average number of grass carps of 1378.5 per ha and common carps with average number of 3885.5 per ha. Similarly, rohu were stocked with average number of 1219.5 per ha and naini with average number of 1168.5 per ha. Thus found the average stocking rate of fingerlings per ha of pond be 12448.7 with almost same number of silver and common carps.

Table 1: Stocking rate of different species of carps (fingerlings/ha)

\begin{tabular}{ll}
\hline Fish species & Mean \\
\hline Silver carps & 3880.5 \\
Bighead carps & 916.2 \\
Grass carps & 1378.5 \\
Common carps & 3885.5 \\
\hline
\end{tabular}




\begin{tabular}{ll} 
& \\
\hline Rohu & 1219.5 \\
Naini & 1168.5 \\
Overall & 12448.7 \\
\hline
\end{tabular}

\subsection{Price rate of Stocking of different species of carps}

Farmers of fish zone; used commonly fingerling size of fish as seed in their pond for production. So, they paid different price rate on different size and of different species. Mostly, farmers used average price rate of NRs.6.13 for silver carps. Similarly, the average price rate of bighead carp was NRs. 5.7 and average price rate of NRs.6.74 was for grass carps. Besides, common carps were stocked with price rate of NRs.6.87, rohu with average rate of NRs. 7.11 and naini with average rate of NRs.7.24.

Table 2: Price rate of Stocking of different species of carps

\begin{tabular}{ll}
\hline Fish species & Mean \pm SD \\
\hline Silver carps & $6.13 \pm 3.07$ \\
Bighead carps & $5.7 \pm 2.06$ \\
Grass carps & $6.74 \pm 1.29$ \\
Common carps & $6.87 \pm 1.15$ \\
Rohu & $7.11 \pm 1.64$ \\
Naini & $7.24 \pm 1.37$ \\
\hline
\end{tabular}

\subsection{Cost, return and profit of fish farming}

Cost is normally expenditure or input for production of any material. Return is the outcome over cost. Profit is difference of return over cost. The average total cost of production by medium farmers was higher than large and small farmers. Contrastingly, the return was higher in medium farmers than large and small farmers. The profit accrued by medium farmers was higher than small and large famers which were found similar with research conducted by Tunde et al. in 2015 and Sharma et al. in 2018[4, 6].

Table 3: Analysis of cost, return and profit/ha

\begin{tabular}{llll}
\hline Type of farmers & Total cost(Rs.) & Return(Rs.) & Profit(Rs.) \\
\hline Small & 612201 & 1291378.2 & 679177.2 \\
Medium & 728265 & 1573462.8 & 845197.8 \\
Large & 706600.2 & 1497995.4 & 791395.2 \\
Overall & 2047066.2 & 4362836.4 & 2315770.2 \\
\hline
\end{tabular}

\subsection{Benefit-cost ratio (B: C)}

Cost of production was calculated by summing the variable cost items in the production process. For calculating gross return, income from product sale was accounted. Benefit cost analysis was done among small, medium and large farmers and it was evident that BCR was higher (2.16) for medium size farmers and lower for smaller farmers (2.11) which was found in consistent with research work of Singh et al. conducted in 2007[7].

Table 4: B: C analysis

\begin{tabular}{ll}
\hline Type of farmers & B:C Ratio \\
\hline Small & 2.11 \\
Medium & 2.16 \\
Large & 2.12 \\
Overall & 2.13 \\
\hline
\end{tabular}

From the survey research, it was found that the minimum production of fish species was $2325 \mathrm{~kg} / \mathrm{ha}$, maximum $10920 \mathrm{~kg} / \mathrm{ha}$ and average $6060.9 \mathrm{~kg} / \mathrm{ha}$ which was satisfactory result. This table shows average production of fish species was 6.06ton/ha. The productivity of that region was 6.68 ton/ha which was found to be greater than the national average[1].

Table 5. Minimum, maximum and mean production $\mathrm{kg} / \mathrm{ha}$

\begin{tabular}{llll}
\hline Particulars & Minimum & Maximum & Mean \\
\hline Production $/ \mathrm{ha}(\mathrm{kg})$ & 2325.00 & 10920.00 & 6060.9 \\
\hline
\end{tabular}

\subsection{Marketing study}

From the present study, it was found that marketing of fish species from farm/pond was having 53 household with $55.78 \%$, similarly; 18 of household with $18.94 \%$ sold fish to near local market themselves. Besides, five of them sold fish from live fish shop with 5.26\%. Among them, 2 of household sold fish to Palpa and Pokhara with 2.10\%; 7 of household sold at Sunauli, India with 7.37\% and 10 of them sold to Parasi, Butwal and Bhairahawa with $10.53 \%$ themselves. Fish marketing was highly concentrated in local area i.e. Rupandehi. Local scale marketing of fish flourished in the study area as obtained in the research findings of Hussen (2019) and Emam $(2010)[8,9]$.

Table 6: Marketing site of fish species

\begin{tabular}{lll}
\hline Fish species marketing site & Frequency & Percentage \\
\hline From farm & 53 & 55.78 \\
Near village local market & 18 & 18.94 \\
Live fish shop & 5 & 5.26 \\
Palpa, Pokhara & 2 & 2.10 \\
Sunauli, India & 7 & 7.37 \\
Parasi, Butwal, Bhairahwa & 10 & 10.53 \\
\hline
\end{tabular}

\subsection{Fish sell}

Table below shows 66.3 percent of farmers sold fish to wholesaler, 30.5 percent to consumers, 26.3 percent to retailer and 26.3 percent to the neighbor which is found non- significant. Wholesalers are the most valuable actors of the value chain followed by consumers, retailers and neighbours which was found in line with the research work of Kassali conducted in 2011 [10].

Table 7: Fish marketed/sold 


\begin{tabular}{llllll}
\hline Particulars & Overall & $\begin{array}{l}\text { Small } \\
\text { farmers(n=27) }\end{array}$ & $\begin{array}{l}\text { Medium } \\
\text { farmers(n=35) }\end{array}$ & $\begin{array}{l}\text { Large } \\
\text { farmers(n=33) }\end{array}$ & $\begin{array}{l}\text { Chi- } \\
\text { Square }\end{array}$ \\
\hline Consumer & $29(30.5)$ & $8(29.6)$ & $9(25.7)$ & $12(36.4)$ & .923 \\
Neighbour & $19(20.0)$ & $7(25.9)$ & $6(17.1)$ & $6(18.2)$ & .839 \\
Retailer & $25(26.3)$ & $8(29.6)$ & $10(28.6)$ & $7(21.2)$ & .688 \\
Wholesaler & $63(66.3)$ & $17(63.0)$ & $21(60.0)$ & $25(75.8)$ & .2 .078 \\
\hline
\end{tabular}

Figures in parentheses indicate percentage

\subsection{Price variation in successive previous four years}

The price rate of different carps species of different successive year was increasing but in very slow and gradual rate.

Maximum, Minimum and mean price of different fish in multiple year

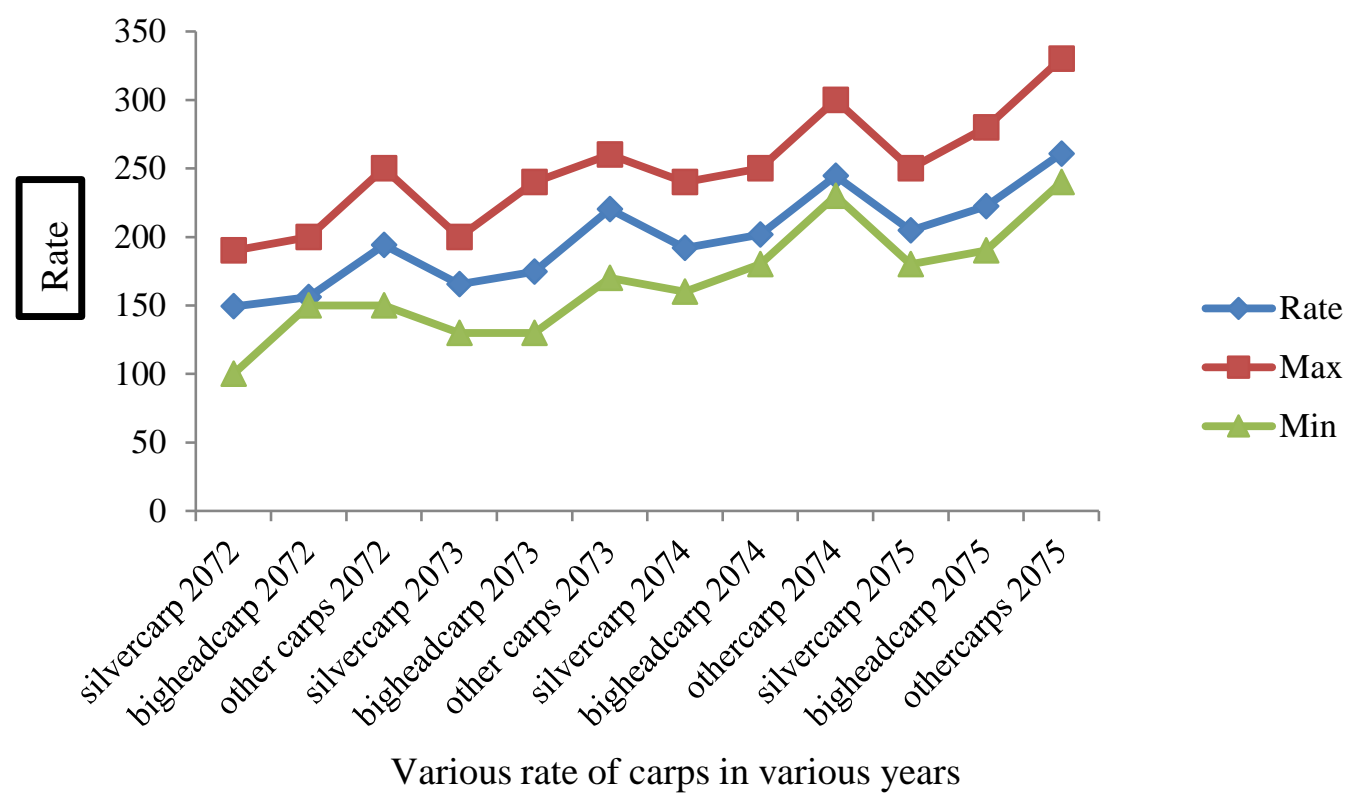

Figure 3: Price variation of fish in previous years

\subsection{Ranking of problems associated to carp polyculture}

In the study area, farmers were facing several problems related to the production. Based on the farmer's perception towards production problems, the ranking of the problems carried out.

\subsection{Ranking of production problems}

The five major problems were high cost of feed, lack of fish technicians, lack of labor, lack of quality fish seed mainly of common carp, and lack of medicine. The index value was obtained and the rank was done based on the high index value. For this ,scale value of 1,0.8,0.6,0.4 and High cost of feed shows most serious problem as its index value is 0.94 so it rank ' $\mathrm{I}$ ' among all 0.2 was used to most serious, serious, moderate, a little bit and least serious problem respectively. The problem index value was found quite similar with the data obtained by Geetu and Misgana $(2015)$ and Sharma et al. $(2018)[6,11]$.

Table 8: Ranking of problems of production

\begin{tabular}{lll}
\hline Production problems & Index & Rank \\
\hline High cost of feed & 0.94 & I \\
Lack of fish technicians & 0.70 & II \\
Lack of quality fish seed (common carp) & 0.57 & III \\
Lack of Labor & 0.45 & IV \\
Lack of medicine & 0.34 & V \\
\hline
\end{tabular}

\subsection{Conclusion}

All the farmers had cultured six types of fish species namely, silver carps, bighead carps, grass carps, common carps, naini and rohu. Among these species the stocking rate of silver carp was highest followed by common carp. It was because the growth rate of silver was highest followed by common carp and these two species were dominated in the pond culture of fish. The average total production was 6.06 ton/ha with average B/C ratio 2.13 which indicates a profitable business. It was also found that the demand of fish is higher in the study area. So, the government should focus on higher production by making available the required infrastructures, especially quality feed in minimum cost as it was the most important problem in the study area. Further researches should be carried out from different sectors to analyze the appropriate feed for the fishes that can be available within local area. Trainings should be expedited in the study area so as to make farmers aware of all the pros and cons of fisheries sub-sector.

\section{References}

[1] CFPCC, “Annual Report 2074/75. Central Fisheries Promotiona and Conservation Centre”, 2018.

[2] FAO, "FAO Fisheries \& Aquaculture - National Aquaculture Sector Overview - Nepal," $2019 . \quad$ [Online]. Available: http://www.fao.org/fishery/countrysector/naso_nepal/en. [Accessed: 06-Jul-2019].

[3] T. Gurung, "Fisheries and Aquaculture Activities in Nepal," 2003, pp. 14-19.

[4] K.M. Tunde Adeniyi Bashir, "Economic Analyze of Costs and Return of Fish Farming in Saki-East Local Government Area of Oyo State, Nigeria," J. Aquac. Res. Dev., vol. 06 (02), 2015. 
[5] S.C. Dhakal, P.P. Regmi, R.B. Thapa, S.K. Sah, and D.B. Khatri-Chhetri, "Profitability and resource use efficiency of buckwheat (Fagopyrum esculentum Moench) production in Chitwan District, Nepal," J. Agric. Environ., vol. 16, pp. 120-131, 2015.

[6] T. Sharma, S.C. Dhakal, R.R. Kattel, K. Gharti, and J. Lamichhane, “Economics of fish production at Chitwan district, Nepal," J. Agric. Nat. Resour., Vol. 1 (1), pp. 21-31, 2018

[7] K. Singh, "Economics and Determinants of Fish Production and Its Effects on Family Income Inequality in West Tripura District of Tripura," Indian Journal of Agricultural Economics, Vol. 6, p. 13, 2007.

[8] Md. A. Husen, “Fish Marketing System in Nepal: Present Status and Future Prospects," Int. J. Appl. Sci. Biotechnol., Vol. 7 (1), pp. 1-5, 2019.

[9] A. A. Emam, “Economics of Fish Production and Marketing: A Case Study of Khartoum State, Sudan," p. 6, 2010.

[10] R. Kassali, O. I. Baruwa, and B.M. Mariama, "Economics of fish production and marketing in the urban areas of Tillabery and Niamey in Niger Republic," Rural Dev., Pp. 7, 2011.

[11] A. Getu and K. Misganaw, “Post-harvesting and Major Related Problems of Fish Production,” Fish. Aquac. J., Vol. 06 (04), 2015. 